\title{
Effect of anti-Müllerian hormone on the regulation of pituitary gonadotropin subunit expression: roles of kisspeptin and its receptors in gonadotroph L $\beta$ T2 cells
}

\author{
Tuvshintugs Tumurbaatar, Haruhiko Kanasaki, Zolzaya Tumurgan, Aki Oride, Hiroe Okada and \\ Satoru Kyo
}

Department of Obstetrics and Gynecology, Faculty of Medicine, Shimane University, Shimane 693-8501, Japan

\begin{abstract}
Anti-Müllerian hormone (AMH) is primarily produced by ovarian granulosa cells and contributes to follicle development. AMH is also produced in other tissues, including the brain and pituitary; however, its roles in these tissues are not well understood. In this study, we examined the effect of AMH on pituitary gonadotrophs. We detected AMH and AMH receptor type 2 expression in L $\beta$ T2 cells. In these cells, the expression of FSH $\beta$ - but not $\alpha$ - and LH $\beta$-subunits increased significantly as the concentration of AMH increased. L $\beta$ T2 cells expressed Kiss-1 and Kiss-1R. AMH stimulation resulted in decreases in both Kiss-1 and Kiss-1R. The siRNA-mediated knockdown of Kiss-1 in L $\beta$ T2 cells did not alter the basal expression levels of $\alpha$-, LH $\beta$-, and FSH $\beta$-subunits. In L $\beta$ T2 cells overexpressing Kiss-1R, exogenous kisspeptin stimulation significantly increased the expression of all three gonadotropin subunits. However, kisspeptin-induced increases in these subunits were almost completely eliminated in the presence of AMH. In contrast, GnRH-induced increases in the three gonadotropin subunits were not modulated by AMH. Our observations suggested that AMH acts on pituitary gonadotrophs and induces FSH $\beta$-subunit expression with concomitant decreases in Kiss-1 and Kiss-1R gene expression. Kisspeptin, but not GnRH-induced gonadotropin subunit expression, was inhibited by AMH, suggesting that it functions in association with the kisspeptin/Kiss-1R system in gonadotrophs.
\end{abstract}

Key words: Anti-Müllerian hormone, Kisspeptin, Gonadotropin, Gonadotropin-releasing hormone

FEMALE REPRODUCTIVE FUNCTION is driven by the hypothalamic-pituitary-gonadal (HPG) axis. It is believed that hypothalamic Kiss-1 neurons (kisspeptinproducing neurons) play a principal role in governing the HPG axis by controlling gonadotropin-releasing hormone $(\mathrm{GnRH})$-expressing neurons in the hypothalamus [1]. GnRH is released from GnRH neurons by kisspeptin and reaches the anterior pituitary via portal circulation. It specifically regulates the synthesis and release of pituitary gonadotropins, luteinizing hormone (LH), and follicle-stimulating hormone (FSH) by changing the amplitude and frequency of their pulsatile release during reproductive cycles [2]. LH and FSH cooperatively

Submitted Jan. 29, 2021; Accepted Mar. 26, 2021 as EJ21-0085 Released online in J-STAGE as advance publication May 15, 2021 Correspondence to: Haruhiko Kanasaki, MD, PhD, Department of Obstetrics and Gynecology, School of Medicine, Shimane University, 89-1 Enya Cho, Izumo, Shimane 693-8501, Japan.

E-mail:kanasaki@med.shimane-u.ac.jp

This work was supported in part by Grants-in-Aid for Scientific Research from the Ministry of Education, Culture, Sports, Science and Technology of Japan (to H.K. and A.O.). affect the gonads and control gametogenesis and steroidogenesis [3]. Kiss-1 neurons have been detected in two hypothalamic areas. Kiss-1 neurons in the arcuate nucleus are involved in the pulsatile release of GnRH, whereas those in the anteroventral periventricular nucleus are involved in GnRH/LH surges in rodents [4, 5]. Kisspeptin and kisspeptin receptor (Kiss-1R) are expressed in peripheral organs other than the brain, including the pituitary gland [6]. Previous studies have revealed that kisspeptin directly stimulates the synthesis and release of the growth hormone prolactin from bovine pituitary cells [7] and gonadotropins from rat pituitary cells [8]. Kisspeptin also has a direct effect on prolactin expression in rat somatolactotroph GH3 cells [9].

Anti-Müllerian hormone (AMH) plays important roles in sexual differentiation and gonadal functions. In males, AMH is produced and secreted exclusively by the Sertoli cells of the testis [10]. It is involved in male sex differentiation by inducing the regression of Müllerian ducts [11]. In females, AMH is primarily produced by granulosa cells of preantral and small antral follicles within the ovary and is believed to regulate the transition from 
resting primordial to growing follicles [12]. Clinically, $\mathrm{AMH}$ is used as a biomarker of testicular function in males [13] and is an indicator of subfertility and infertility [14] in reproductive women. It is a diagnostic marker for polycystic ovary syndrome [15].

Several studies have reported relations between $\mathrm{AMH}$ and components of the HPG axis. AMH receptor expression has been detected in GnRH neurons, and AMH potently activates GnRH neurons and induces LH secretion in mice [16]. For pituitary gonadotropins, AMH receptor is expressed in the L $\beta \mathrm{T} 2$ mouse gonadotroph cell model and AMH has a stimulatory effect on endogenous FSH $\beta$-subunit gene expression in these cells [17]. Although AMH stimulates basal FSH secretion in the anterior pituitary of heifers, it inhibits GnRH-induced FSH secretion [18]. AMH itself is also expressed in bovine pituitary gonadotrophs [19].

The importance of Kiss-1R in the regulation of hypothalamic GnRH is well documented; however, previous studies have demonstrated that kisspeptin and Kiss-1R are also involved in the control of pituitary gonadotrophs $[20,21]$. In this study, using the L $\beta$ T2 gonadotroph cell model, we confirmed that AMH induces FSH $\beta$-subunit gene expression. Furthermore, we evaluated whether the Kiss-1 and Kiss-1R systems are involved in gonadotropin gene expression in these cells.

\section{Materials and Methods}

\section{Materials}

The following chemicals and reagents were obtained from the indicated sources: fetal bovine serum (FBS) (Invitrogen, Carlsbad, CA); AMH (R\&D Systems, Inc., Minneapolis, MN); kisspeptin-10 (ANA SPEC, Fremont, CA); Dulbecco's modified Eagle's medium (DMEM), GnRH, and penicillin-streptomycin (Sigma-Aldrich Co., St. Louis, MO).

\section{Cell culture}

L $\beta$ T2 cells were plated on 35-mm tissue culture dishes and incubated in high-glucose DMEM containing 10\% heat-inactivated FBS and 1\% penicillin-streptomycin at $37^{\circ} \mathrm{C}$ in a humidified atmosphere of $5 \% \mathrm{CO}_{2}$ in air. Cells were used for experiments after $24 \mathrm{~h}$. For stimulation, the cells were incubated with or without (control) test reagents at the indicated concentrations for $24 \mathrm{~h}$ in highglucose DMEM containing 1\% heat-inactivated FBS and $1 \%$ penicillin-streptomycin.

\section{Western blot analysis}

Cell extracts were lysed on ice with radioimmunoprecipitation assay buffer (phosphate-buffered saline, 1\% NP-40, $0.5 \%$ sodium deoxycholate, and $0.1 \%$ sodium dodecyl sulfate [SDS]) containing $0.1 \mathrm{mg} / \mathrm{mL}$ phenylmethyl sulfonyl fluoride, $30 \mathrm{mg} / \mathrm{mL}$ aprotinin, and $1 \mathrm{mM}$ sodium orthovanadate, scraped for $20 \mathrm{~s}$, and centrifuged at $14,000 \times \mathrm{g}$ for $10 \mathrm{~min}$ at $4^{\circ} \mathrm{C}$. The protein concentration in cell lysates was measured using the Bradford method. Denatured protein $(20 \mu \mathrm{g}$ per well) was resolved by SDS polyacrylamide gel electrophoresis (PAGE) according to standard protocols and transferred onto polyvinylidene difluoride membranes (Hybond-P PVDF; Amersham Biosciences, Little Chalfont, UK). Membranes were blocked for $2 \mathrm{~h}$ at room temperature in Blotto ( $5 \%$ milk in Tris-buffered saline). The membranes were incubated with an anti-AMH mouse monoclonal antibody (sc-365643) [22] (1:100 dilution; Santa Cruz Biotechnology, Inc., Dallas, TX), anti-AMHR2 rabbit polyclonal antibody (ab 197148) (1:1,000 dilution; Abcam, Cambridge, UK), anti-kisspeptin rabbit polyclonal antibody (ab 19028) [23] (1:100 dilution; Abcam), or anti-Kiss-1R rabbit polyclonal antibody (ab 137483) [24] (1:500 dilution; Abcam) in Blotto overnight at $4{ }^{\circ} \mathrm{C}$ and washed for $10 \mathrm{~min}$ three times with Tris-buffered saline/1\% Tween. A subsequent incubation with horseradish peroxidase (HRP)-conjugated secondary antibodies (anti-mouse antibody, 1:15,000 dilution; anti-rabbit antibody, 1:20,000 dilution) was performed for $1 \mathrm{~h}$ at room temperature in Blotto, and additional washes were performed as needed. Following enhanced chemiluminescence detection (Amersham Biosciences), the membranes were exposed to an X-ray film (Fujifilm, Tokyo, Japan). Tissues from rat ovaries or rat brains were used as a positive control, and an antibody for $\beta$-actin was used as an internal control. For comparisons of protein expression levels, images were analyzed by densitometry (ImageJ, National Institutes of Health, Bethesda, MD), and the intensities of protein bands were normalized to those of $\beta$-actin to correct for protein loading.

\section{$R N A$ preparation, reverse transcription, $P C R$, and quantitative real-time PCR}

Total RNA was extracted from cells using TRIzol-LS (Invitrogen) according to the manufacturer's instructions. To obtain cDNA, $1.0 \mu \mathrm{g}$ of total RNA was reverse transcribed using an oligo-dT primer (Promega, Madison, WI) and prepared using a First-Strand cDNA Synthesis Kit (Invitrogen) and reverse transcription (RT) buffer. The preparation was supplemented with $10 \mathrm{mM}$ dithiothreitol, $1 \mathrm{mM}$ of each dNTP, and $200 \mathrm{U}$ of RNase inhibitor/human placenta ribonuclease inhibitor (Code No. 2310; Takara, Tokyo, Japan) in a final volume of 10 $\mu \mathrm{L}$. The reaction was incubated at $37^{\circ} \mathrm{C}$ for $60 \mathrm{~min}$. Gonadotropin subunits ( $\alpha, \mathrm{LH} \beta$, and FSH $\beta$ ), Kiss- 1 , and Kiss-1R mRNAs were quantified by quantitative realtime PCR (ABI Prism 7000; Applied Biosystems, Foster 
City, CA) according to the manufacturer's instructions (User Bulletin No. 2) using Universal ProbeLibrary Probes and FastStart Master Mix (Roche Diagnostics, Mannheim, Germany). The PCR primers were designed based on published sequences of gonadotropin- $\alpha$ [25], -LH $\beta$, -FSH $\beta$ [26], Kiss-1, and Kiss-1R [27]. The simultaneous measurement of target mRNAs and GAPDH permitted the normalization of transcript levels. Each set of primers included a no-template control. Thermal cycling conditions were as follows: $10 \mathrm{~min}$ of denaturation at $95^{\circ} \mathrm{C}$, followed by 40 cycles of $95^{\circ} \mathrm{C}$ for $15 \mathrm{~s}$ and $60^{\circ} \mathrm{C}$ for $1 \mathrm{~min}$. Reactions were followed by a melting curve analysis $\left(55^{\circ} \mathrm{C}-95^{\circ} \mathrm{C}\right)$. To determine PCR efficiency, 10 fold serial dilutions of cDNA were used as previously described [28]. PCR conditions were optimized to obtain $>95 \%$ efficiency, and only those reactions with efficiencies between $95 \%$ and $105 \%$ were included in subsequent analyses. Relative differences in cDNA concentration between baseline and experimental conditions were calculated using the comparative threshold cycle (Ct) method [29]. Briefly, for each sample, $\Delta \mathrm{Ct}$ was calculated for normalization against the internal control using the following equation: $\Delta \mathrm{Ct}=\Delta \mathrm{Ct}$ (gene) $\mathrm{Ct}(G A P D H)$. To obtain differences between experimental and control conditions, $\Delta \Delta \mathrm{Ct}$ was calculated as $\Delta \mathrm{Ct}$ (sample) $-\Delta \mathrm{Ct}$ (control). Relative mRNA levels were calculated using the following equation: fold difference $=2^{\Delta \Delta \mathrm{Ct}}$. For the detection of Kiss- 1 and Kiss-1R, PCR amplicons were separated by electrophoresis on agarose gels and visualized by ethidium bromide staining. cDNA from rat brain tissues was used as a positive control.

\section{Receptor overexpression and small interfering $R N A$ ( $\operatorname{siRNA}$}

The human GPR54 (Kiss1R) vector was generously provided by Dr. Ursula Kaiser (Brigham and Women's Hospital and Harvard Medical School, Boston, MA) [30]. Cells were transiently transfected via electroporation with Kiss1-R expression vectors. An empty vector (pCI-neo) served as the mock control. To silence the expression of Kiss-1, the following sequences were used: sense, CUUCUAGACUUGUGCAAUAtt, and antisense, UAUUGCACAAGUCUAGAAGtt (Santa Cruz Biotechnology, Inc.). Control siRNA (Santa Cruz Biotechnology, Inc.) was used as a negative control for Kiss-1 siRNA. Transfection of siRNA oligonucleotides was performed by electroporation.

\section{SRE promoter luciferase assay}

Cells were transiently transfected with the Kiss1R expression vector, $2.0 \mu \mathrm{g} / \mathrm{well} \mathrm{pSRE}$ (serum response element)-Luc (containing five tandem repeats of the SRE enhancer (X4) upstream of the firefly luciferase gene), and $0.1 \mu \mathrm{g}$ of PRL-TK (Promega), which expresses Renilla luciferase, by electroporation. An empty vector (pCi-neo) served as the mock control. After incubation with agonists for $6 \mathrm{~h}$, cells were washed with ice-cold PBS and lysed with passive lysis buffer ( $5 \times$; Promega). After centrifugation at $15,000 \mathrm{rpm}$ and $4^{\circ} \mathrm{C}$, firefly luciferase and Renilla luciferase activity levels were measured in the supernatant using the Dual-Luciferase Reporter Assay System and a TD-20/20 luminometer (both from Promega) according to the manufacturer's protocol. Firefly luciferase activity was normalized to that of Renilla luciferase to correct for the transfection efficiency, and the results are expressed as the increase (fold change) relative to the unstimulated control.

\section{Statistical analysis}

All experiments were repeated independently three times. When mRNA expression was determined, two sets of samples were prepared and stimulated by different conditions. These two samples were assayed in duplicate. From four sets of data, mean values were determined. The same experiments were repeated three times, and the final means \pm standard errors of the mean (SEM) were determined from the three sets of means. For the luciferase assay, three samples were assayed in one experiment. The same experiment was repeated three times, and the three averages were obtained for statistical analyses. Averages from independent experiments were analyzed by one-way or two-way analysis of variance (ANOVA) with Bonferroni's post hoc tests or by Student's $t$-tests using Prism (GraphPad Software, Inc., La Jolla, CA). $p<0.05$ was considered statistically significant.

\section{Results}

\section{Effect of AMH on gonadotropin subunit expression in LBT2 cells}

First, we evaluated AMH receptor expression in the mouse-derived pituitary gonadotroph cell line L $\beta$ T2. By western blotting, we found that L $\beta$ T2 cells expressed AMHR2 as well as AMH. Expression was also detected in cell extracts from the rat ovary, used as a positive control (Fig. 1A). Next, L $\beta$ T2 cells were stimulated with $\mathrm{AMH}$ and changes in gonadotropin subunit gene expression were evaluated by real-time RT-PCR. AMH did not modify the basal expression of gonadotropin $\alpha$ - and LH $\beta$-subunits, even when the AMH dose was increased to $10 \mathrm{nM}$ (Fig. $1 \mathrm{~B}$ and $\mathrm{C}$ ). In contrast, FSH $\beta$-subunit expression increased significantly by $2.00 \pm 0.68$-fold in response to $10 \mathrm{nM}$ AMH (Fig. 1D). 
A

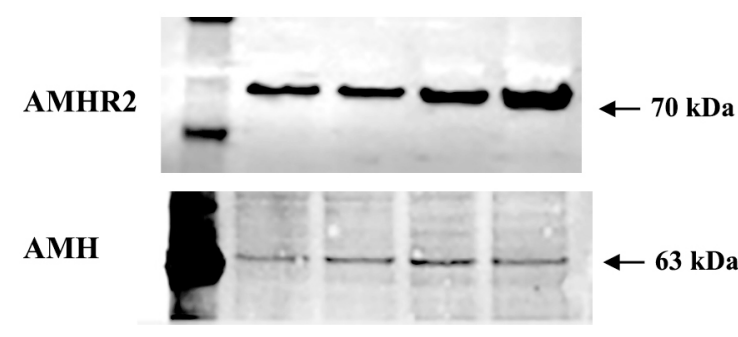

$\boldsymbol{\beta}$-actin

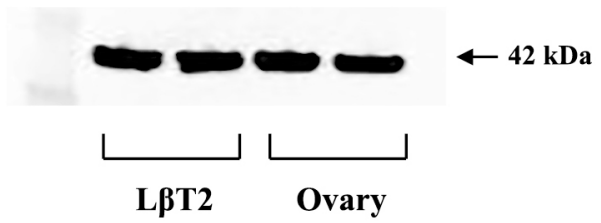

B

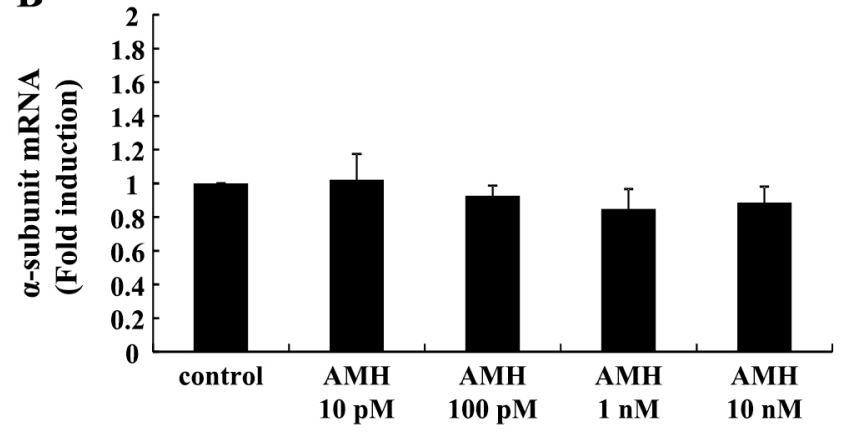

C
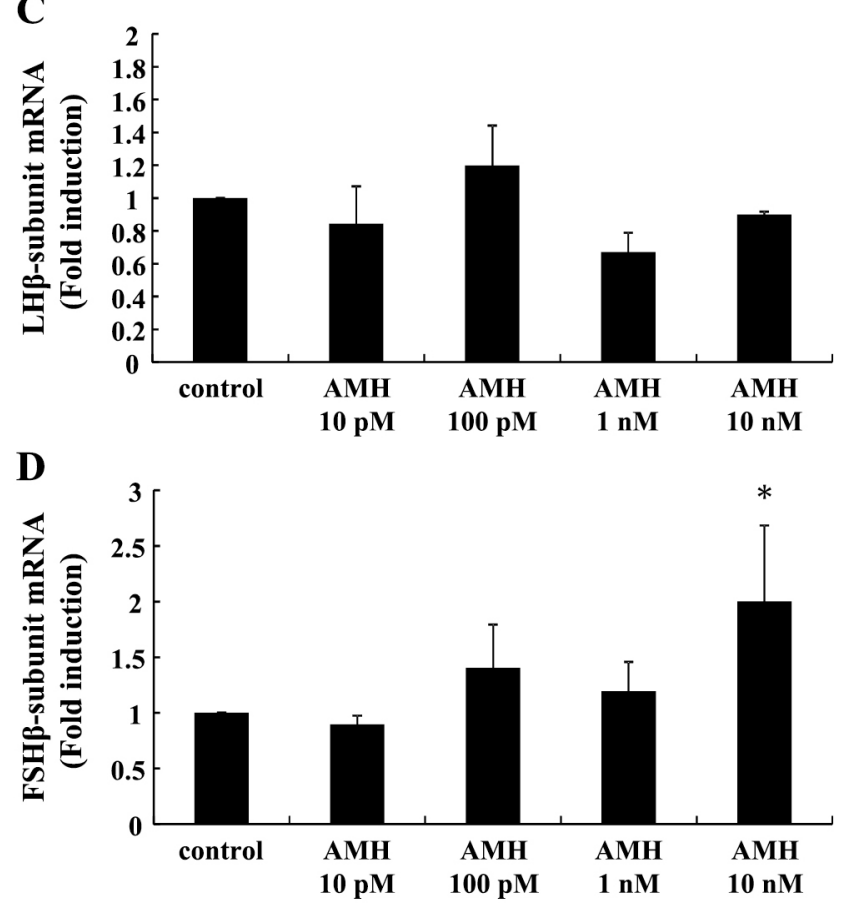

Fig. 1 Expression of AMHR2 and AMH and the effect of AMH on gonadotropin subunit gene expression in L $\beta$ T2 cells. Cell lysates (20 $\mu \mathrm{g}$ ) from LBT2 cells were analyzed by SDS-PAGE, immunoblotting, and incubation with antibodies against AMHR2 and AMH. The bands were visualized using an HRP-conjugated secondary antibody. Rat ovary tissues were used as positive controls (A). L $\beta$ T2 cells were stimulated with the indicated concentrations of AMH for $24 \mathrm{~h}$, after which mRNA was extracted and reverse transcribed. Gonadotropin $\alpha-(B)$, LH $\beta$ - (C), and FSH $\beta$ - (D) subunit mRNA levels were measured by quantitative real-time PCR. Results are expressed as the fold induction relative to unstimulated cells. Each experiment was performed with duplicate samples, and each sample was assayed in duplicate. Means were determined from four sets of data. We repeated the same experiment three times and the final means \pm SEM were determined from three sets of means. ${ }^{*} p<0.05 v s$. control. Statistical significance was determined by one-way ANOVA with Bonferroni's post hoc tests.

\section{Effect of AMH on Kiss-1 and Kiss-1R gene expression in LBT2 cells}

Kiss-1 and its receptor Kiss-1R were expressed in L $\beta$ T2 cells at the mRNA (Fig. 2A) and protein levels (Fig. 2B). AMH affected Kiss-1 and Kiss-1R gene expression in L $\beta$ T2 cells. Kiss-1 gene expression in L $\beta$ T2 cells decreased significantly in response to AMH in the range of $10 \mathrm{pM}(0.79 \pm 0.18$-fold $)$ to $10 \mathrm{nM}(0.34$ \pm 0.07 -fold). (Fig. 3A). Similar to the results for Kiss-1, Kiss $1 R$ gene expression was also repressed by AMH. For $10 \mathrm{pM}$ and $10 \mathrm{nM}$ AMH, Kiss $1 R$ expression decreased significantly by $0.67 \pm 0.16$-fold and $0.66 \pm 0.13$-fold, respectively. AMH decreased Kiss $1 R$ levels $0.72 \pm 0.07$ fold at $100 \mathrm{pM}$ and $0.77 \pm 0.06$-fold at $1 \mathrm{nM}$ relative to levels in unstimulated controls; however, the decreases in concentrations were not statistically significant (Fig. 3B).

\section{Effects of Kiss-1 knockdown on gonadotropin subunit gene expression in LBT2 cells}

To examine the roles of endogenous kisspeptin in L $\beta$ T2 cells, Kiss-1-specific siRNA was applied. After Kiss-1 siRNA transfection, the basal expression of kisspeptin in L $\beta T 2$ cells was clearly lower than that in cells 
A

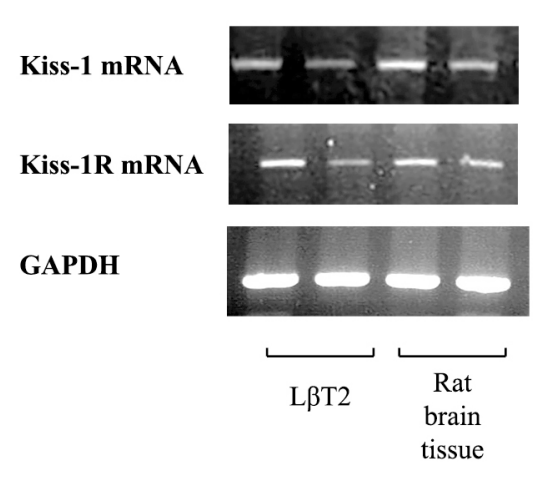

B

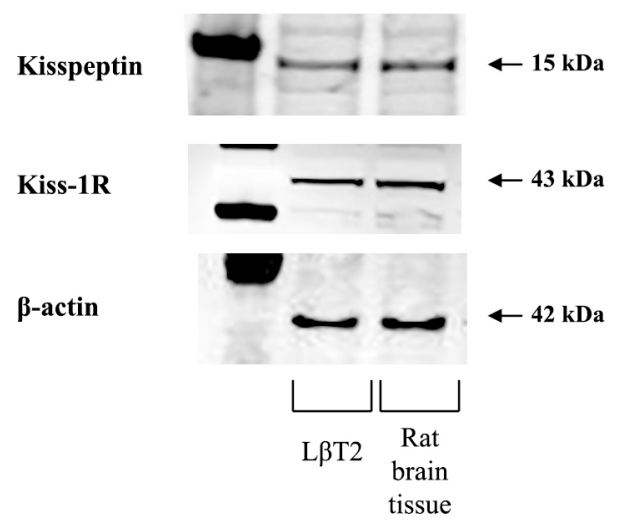

Fig. 2 Expression of kisspeptin and its receptors in L $\beta$ T2 cells. (A) Kiss-1 and Kiss1R expression in L $\beta$ T2 cells, as determined by PCR amplification and agarose gel electrophoresis. (B) Cell lysates $(20 \mu \mathrm{g})$ from L $\beta T 2$ cells were analyzed by SDS-PAGE, immunoblotting, and incubation with antibodies against Kiss-1 and Kiss-1R. The bands were visualized using an HRP-conjugated secondary antibody. cDNAs or lysates from rat brain tissues were used as positive controls.

transfected with negative control siRNA (Fig. 4A). Quantitative analysis demonstrated that kisspeptin protein expression was significantly decreased by 20 to $32 \%$ after transfection of Kiss-1 siRNA above 25 pM (Fig. 4B). Although transfection with $100 \mathrm{pM}$ siRNA was sufficient to reduce kisspeptin expression in cells, basal expression levels of gonadotropin subunits $\alpha, \operatorname{LH} \beta$, and FSH $\beta$ did not differ from those in cells transfected with the same amount of negative control siRNA (Fig. 4C-E).

\section{Effect of AMH on kisspeptin-induced gonadotropin subunit expression}

Effects of AMH on kisspeptin-induced gonadotropin subunit gene expression were examined. We have previously reported that $\mathrm{L} \beta \mathrm{T} 2$ cells do not respond to exogenous kisspeptin although they express Kiss1R [31]. SRE is a DNA domain that binds to extracellular signalregulated kinase (ERK)-mediated transcription factors. In an SRE reporter gene assay, kisspeptin-10 (KP10), a peptide fragment of the Kiss-1 precursor, failed to stimulate SRE promoter activity in empty vector (mock)transfected L $\beta$ T2 cells (Fig. 5A). In mock-transfected L $\beta$ T2 cells, KP10 failed to stimulate $\alpha$-, LH $\beta$-, and FSH $\beta$-subunit expression, as previously reported (data not shown). In contrast, in L $\beta \mathrm{T} 2$ cells overexpressing Kiss1R, SRE promoter activity increased dramatically by KP10 stimulation (98.54 \pm 17.47 -fold) (Fig. 5B). KP10 significantly increased the expression of all gonadotropin subunits in L $\beta T 2$ cells overexpressing Kiss1R. However, KP-10-induced gonadotropin subunit expression was dramatically inhibited by treatment with both KP10 and AMH. KP10 increased $\alpha$-subunit gene expression by $2.51 \pm 0.62$-fold, but expression only increased by $1.38 \pm 0.54$-fold relative to levels in the control in the

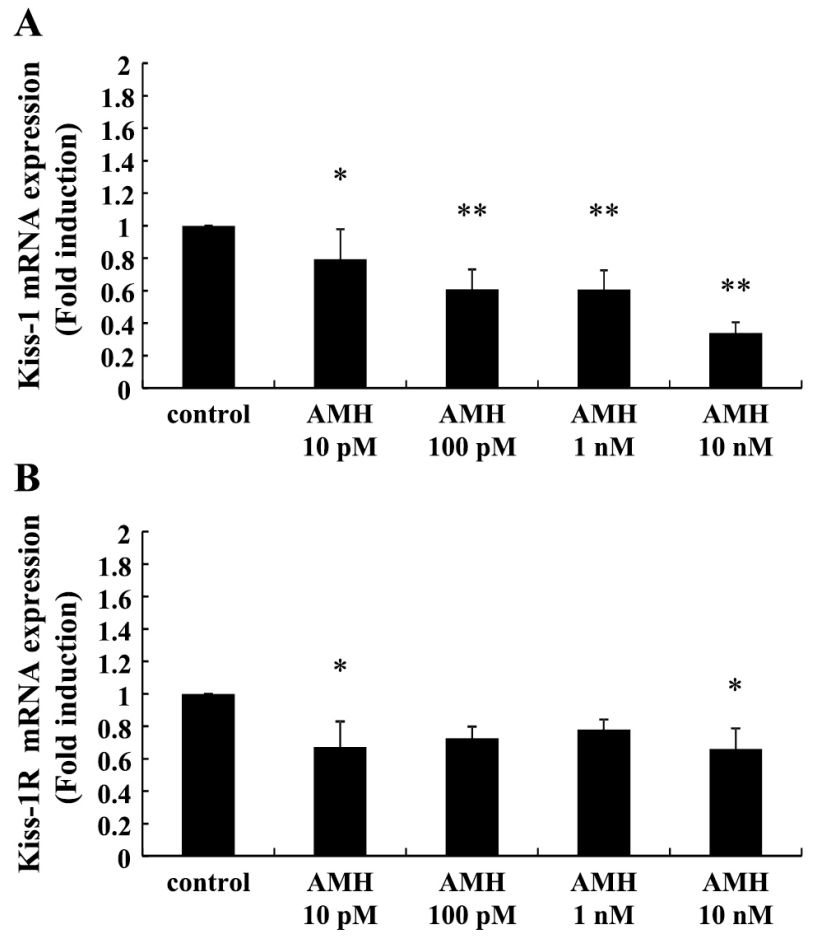

Fig. 3 Effect of AMH on the expression of Kiss-1 and Kiss-1R in L $\beta$ T2 cells. L $\beta$ T2 cells were stimulated with the indicated concentrations of AMH for $24 \mathrm{~h}$, after which mRNA was extracted and reverse transcribed. Kiss-1 (A) and Kiss-1R (B) mRNA levels were measured by quantitative real-time PCR. Results are expressed as the fold induction relative to unstimulated cells. Each experiment was performed with duplicate samples, and each sample was assayed in duplicate. Means were determined from four sets of data. We repeated the same experiment three times and the final means \pm SEM were determined from three sets of means. $* * p<0.01,{ }^{*} p<$ 0.05 vs. control. Statistical significance was determined by one-way ANOVA with Bonferroni's post hoc tests. 
A

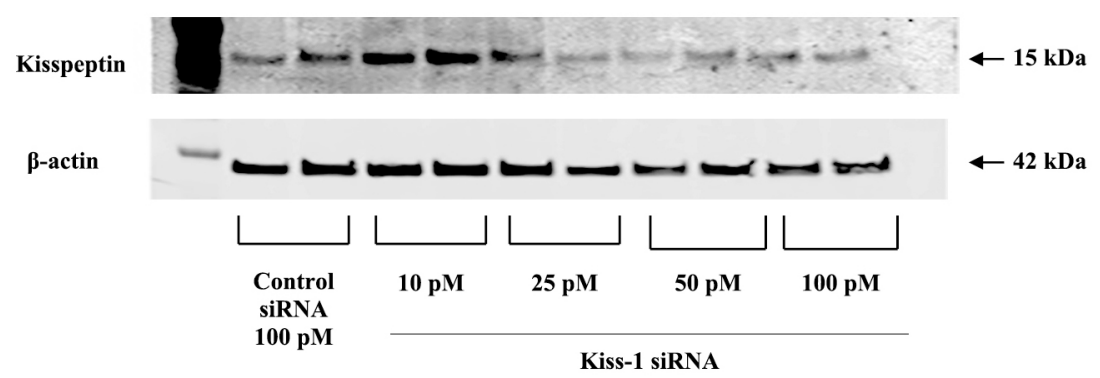

B

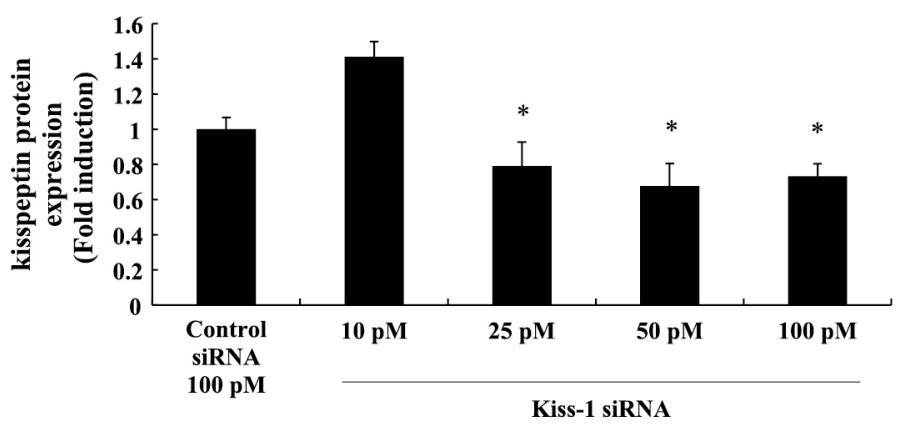

C

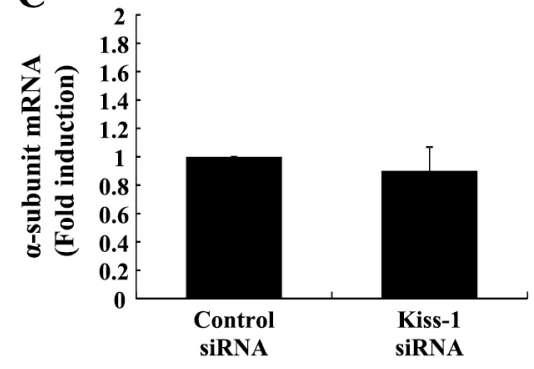

D
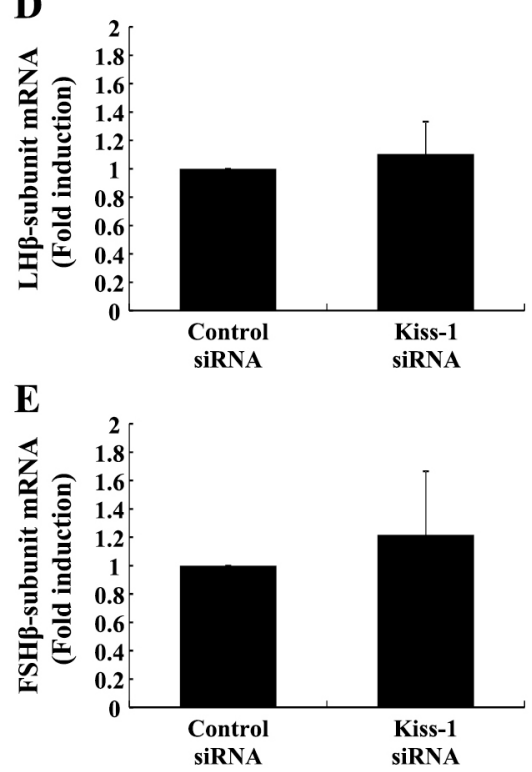

Fig. 4 Effects of Kiss-1 gene knockdown on gonadotropin subunit expression in L $\beta$ T2 cells. (A) L $\beta$ T2 cells were transfected with the indicated concentrations of Kiss-1 siRNA by electroporation, and cell lysates were analyzed by SDS-PAGE, immunoblotting, and incubation with antibodies against kisspeptin. Bands were visualized using an HRP-conjugated secondary antibody. (B) Scanning densitometry of bands was performed using ImageJ to determine differences in kisspeptin protein expression, with normalization to levels of $\beta$-actin. cDNAs or lysates from rat brain tissues were used as positive controls. (C, D, E) Kiss-1 siRNA (100 pM) was introduced to L $\beta$ T2 cells and cultured for $48 \mathrm{~h}$. Gonadotropin $\alpha-(\mathrm{C})$, LH $\beta$ - (D), and FSH $\beta$ - (E) subunit mRNA levels were measured by quantitative real-time PCR. Results are expressed as the fold induction relative to unstimulated cells. Each experiment was performed with duplicate samples, and each sample was assayed in duplicate. Means were determined from four sets of data. We repeated the same experiment three times and the final means \pm SEM were determined from three sets of means. Statistical significance was determined by one-way ANOVA with Bonferroni's post hoc tests or Student's $t$-tests. ${ }^{*} p<0.05 v s$. control.

presence of AMH (Fig. 5D). Similarly, LH $\beta$-subunit expression increased by $5.65 \pm 1.22$-fold by KP10 but only increased by $1.71 \pm 0.34$-fold relative to levels in the control after co-treatment with AMH (Fig. 5E). KP10 significantly increased FSH $\beta$-subunit expression by 3.66 \pm 0.63 -fold. AMH itself also significantly increased FSH $\beta$ expression by $2.46 \pm 0.56$-fold. When cells were stimulated together with KP10 and AMH, the KP-10induced increase in FSH $\beta$ expression was significantly inhibited (Fig. 5F). However, SRE-promoter activity induced by KP10 was not inhibited in the presence of AMH in L $\beta$ T2 cells overexpressing Kiss-1R (Fig. 5C).

\section{Effect of AMH on GnRH-induced gonadotropin subunit expression}

Finally, we evaluated the effect of AMH on GnRH- induced gonadotropin subunit expression. As expected, GnRH significantly stimulated the expression of all three gonadotropin subunits. AMH did not modulate the basal expression levels of $\alpha$ - and LH $\beta$-subunits and did not interfere with the effects of GnRH on these subunits (Fig. 6A, B). Both GnRH and AMH increased FSH $\beta$ subunit expression, and GnRH and AMH did not have synergistic effects (Fig. 6C).

\section{Discussion}

Using L $\beta$ T2 cells as a model for pituitary gonadotrophs, we found that $\mathrm{AMH}$ could stimulate $\mathrm{FSH} \beta$ subunit gene expression. We also revealed that $\mathrm{AMH}$ affects Kiss-1 and Kiss-1R expression in these cells. Because AMH inhibited the effects of kisspeptin but not 
A
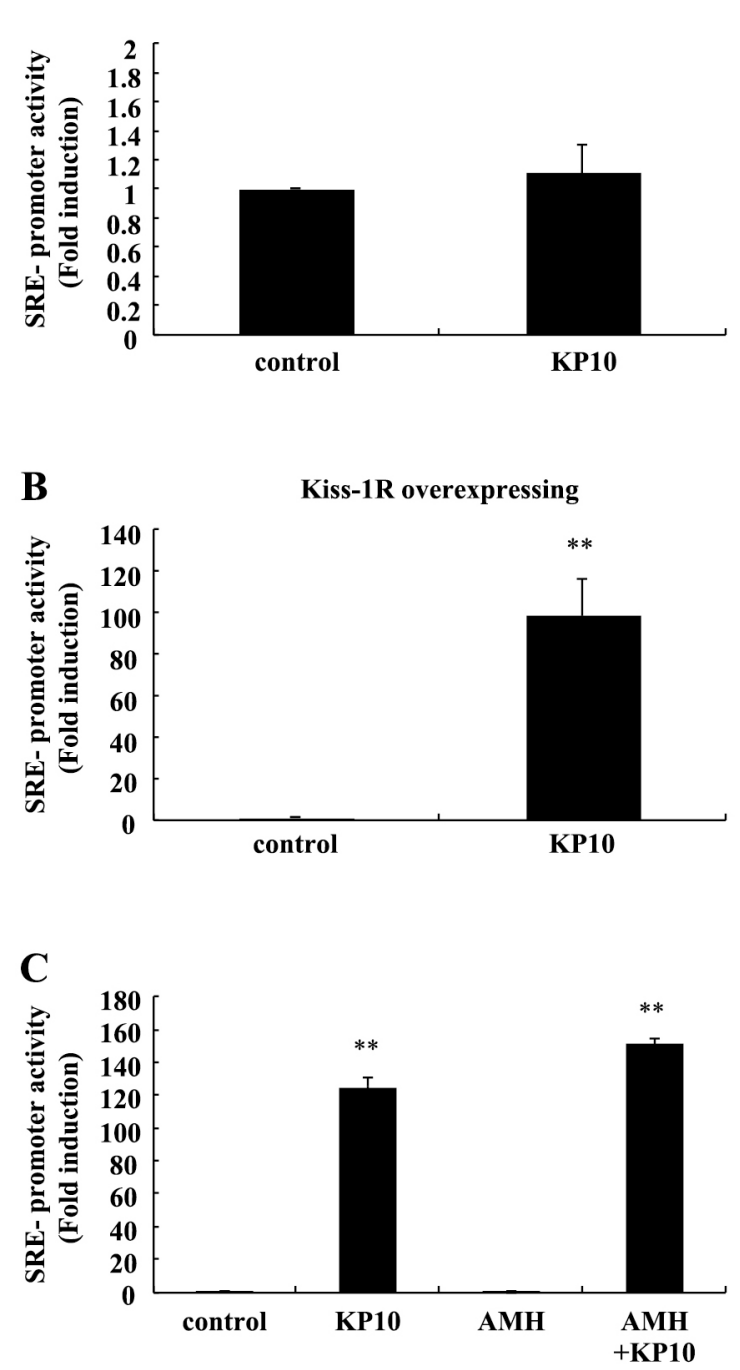
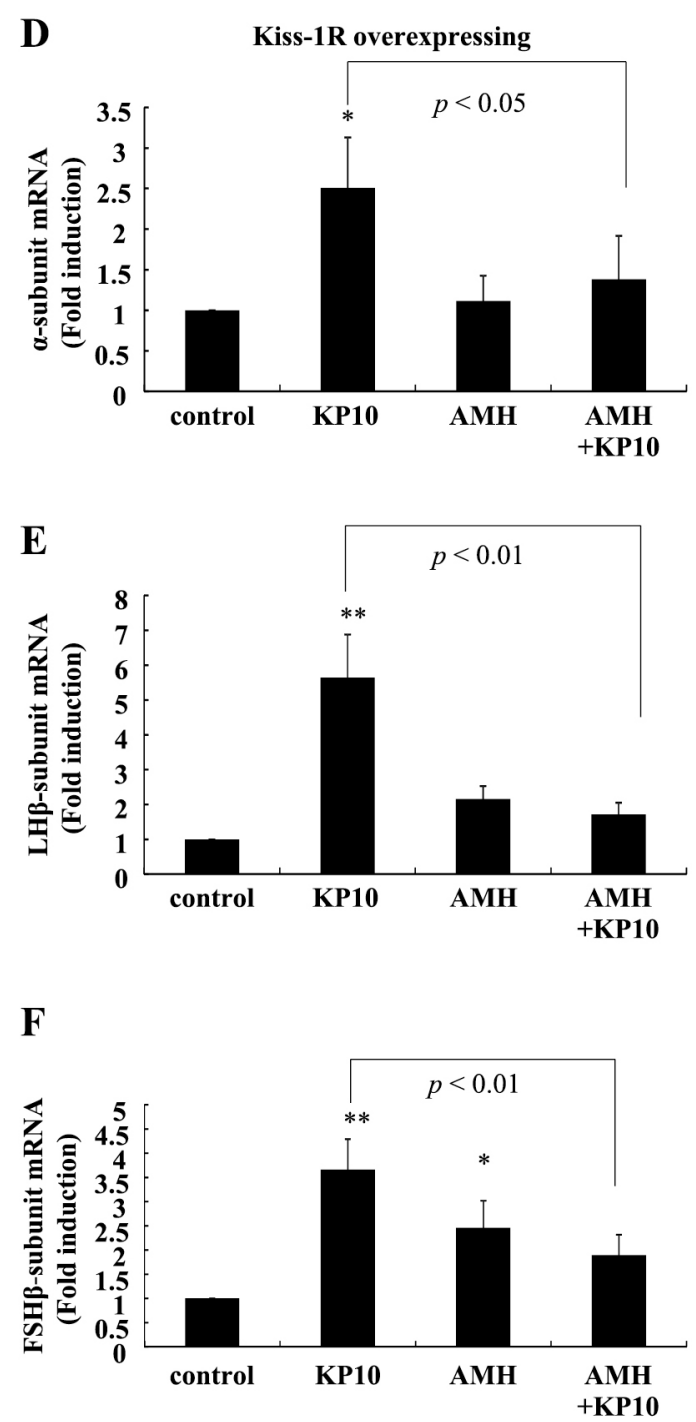

Fig. 5 Effect of AMH on kisspeptin-induced SRE-promoter activity and gonadotropin subunit expression in Kiss-1R-overexpressing L $\beta$ T2 cells. L $\beta T 2$ cells were transfected with $1.0 \mu \mathrm{g}$ of the mock (A) or Kiss1R-expressing vector (B) together with $2.0 \mu \mathrm{g} / \mathrm{well}$ pSRE-Luc and $0.1 \mu \mathrm{g}$ of PRL-TK (Promega). Forty-eight hours after transfection, cells were treated with $100 \mathrm{nM}$ kisspeptin-10 (KP10) (A, B), AMH (100 nM), or both (C) for $6 \mathrm{~h}$. A firefly luciferase assay was performed to examine SRE promoter activity, which was normalized to Renilla luciferase activity and expressed as the fold induction over unstimulated controls. Three samples were assayed in one experiment. We repeated the same experiment three times, and three averages were compared by Student's $t$ tests (A, B) or two-way ANOVA with Bonferroni's post hoc tests (C). L $\beta$ T2 cells were transfected with $1.0 \mu \mathrm{g}$ of the Kiss1Rexpressing vector (D-F). At $48 \mathrm{~h}$ after transfection, cells were stimulated with KP10, AMH, or both KP10 and AMH for $24 \mathrm{~h}$. Then, gonadotropin $\alpha$ - (D), LH $\beta$ - (E), and FSH $\beta$ - (F) subunit mRNA levels were measured by quantitative real-time PCR. Results are expressed as the fold induction relative to unstimulated cells. Each experiment was performed with duplicate samples, and each sample was assayed in duplicate. Means were determined from four sets of data. We repeated the same experiment three times and the final means \pm SEM were determined from three sets of means. Statistical significance was determined by two-way ANOVA with Bonferroni's post hoc tests. ${ }^{*} p<0.01,{ }^{*} p<0.05$ vs. control. Differences between KP10 and KP10+AMH in gonadotropin $\alpha$ - (D), LH $\beta$ - (E), and FSH $\beta$-subunits (F) were statistically significant.

GnRH on gonadotropin subunit expression, we speculated that AMH might function in association with the Kiss-1/Kiss-1R system in gonadotrophs.

Although the primary role of AMH has been described at the level of the ovary, AMHR2 has been detected in both the brain and pituitary gland $[14,32]$. Furthermore, previous studies have shown that bovine pituitary gonadotrophs and mouse L $\beta$ T2 gonadotrophs express AMHR2 [14, 19], suggesting that AMH contributes to gonadotropin regulation. In addition, similar to previous studies showing that AMH could regulate FSH $\beta$ - but not $\alpha$ - and LH $\beta$-subunits [17, 33], we observed the specific regulation of FSH $\beta$-subunit expression by AMH in L $\beta \mathrm{T} 2$ cells. Our results further revealed that AMH could 

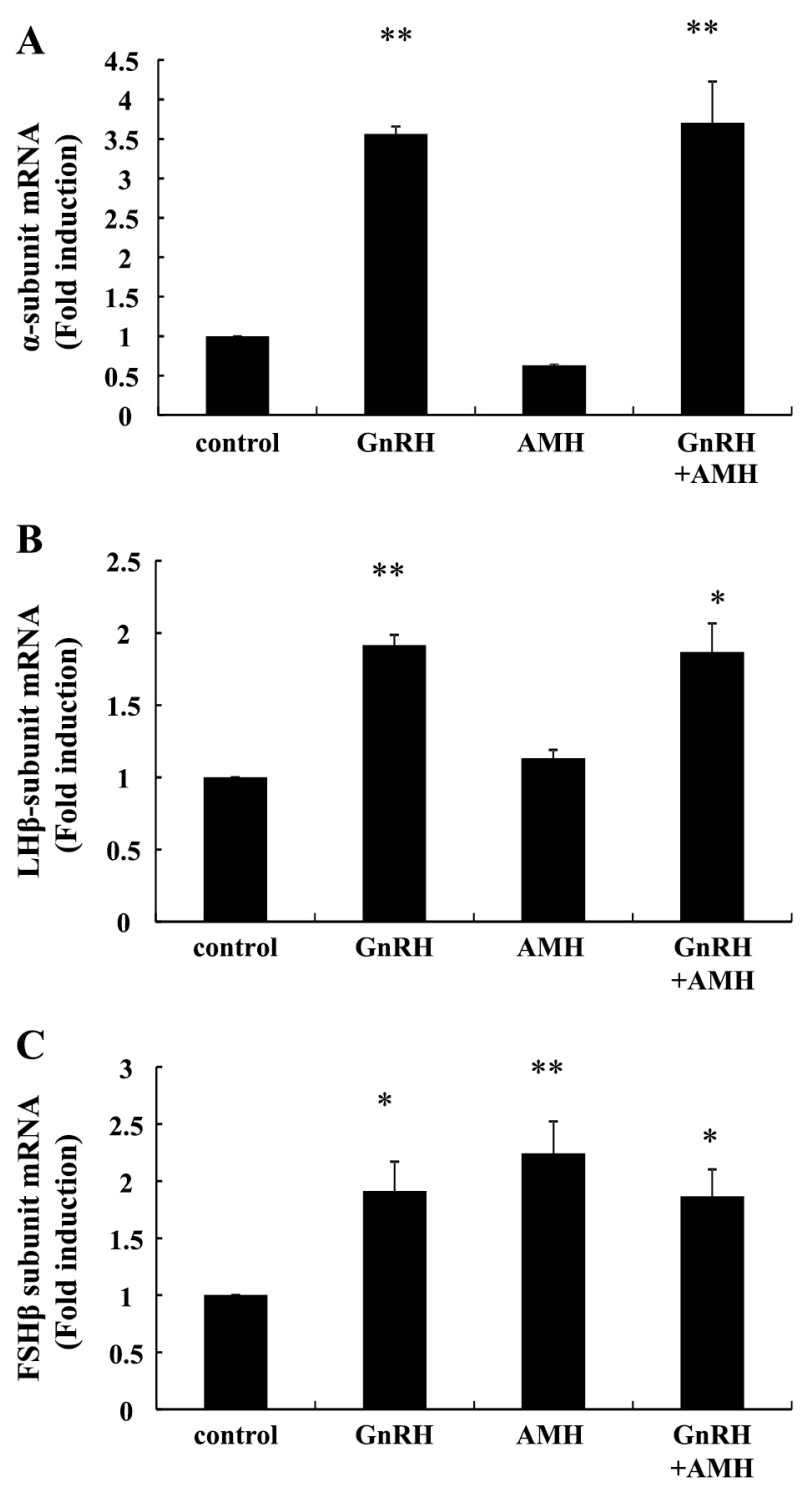

Fig. 6 Effect of AMH on GnRH-induced gonadotropin subunit expression. L $\beta$ T2 cells were stimulated with GnRH, $\mathrm{AMH}$, or both for $24 \mathrm{~h}$. Then, gonadotropin $\alpha-(\mathrm{A}), \mathrm{LH} \beta$ (B), and FSH $\beta$ - (C) subunit mRNA levels were measured by quantitative real-time PCR. Results are expressed as the fold induction relative to unstimulated cells. Each experiment was performed with duplicate samples, and each sample was assayed in duplicate. Means were determined from four sets of data. We repeated the same experiment three times and the final means \pm SEM were determined from three sets of means. Statistical significance was determined by two-way ANOVA with Bonferroni's post hoc tests. ${ }^{* *} p<0.01,{ }^{*} p<0.05$ vs. control.

influence the effect of kisspeptin on pituitary gonadotropin subunit expression.

The importance of Kiss-1R in regulating hypothalamic GnRH is well documented, but kisspeptin and Kiss-1R are also involved in controlling pituitary hormones related to gonadotropins. Kiss-1R has been detected in rat pituitary cells including gonadotrophs [20], and kisspeptin has been reported to act directly on the pituitary gland and to stimulate the release of gonadotropins, prolactin, and growth hormone $[8,21]$. Kisspeptin itself is also expressed in the pituitary gland. Kiss-1 expression in the pituitary gland is upregulated by estradiol, whereas Kiss-1R is upregulated by GnRH [20]. Pituitary gonadotroph L $\beta$ T2 cells also express Kiss-1 and Kiss-1R. Our results indicated that the kisspeptin/Kiss-1R system involving gonadotropin subunit gene expression in these cells is negatively regulated by AMH. Both Kiss-1 and Kiss-1R expression were significantly repressed in the presence of AMH. Therefore, we next evaluated how pituitary gonadotrophs change in response to reductions in Kiss-1 and Kiss-1R. The repression of endogenous Kiss-1 in L $\beta$ T2 cells by siRNA transfection did not influence the basal expression of three gonadotropin subunits. Therefore, AMH induced a decrease in Kiss-1 and an increase in FSH $\beta$-subunit expression without affecting $\alpha$ and LH $\beta$-subunit expression in L $\beta$ T3 cells.

The AMH-induced reduction in Kiss-1R seemed to be involved in the regulation of gonadotropin subunit genes, based on the observation that kisspeptin-induced increases in gonadotropin subunit expression were attenuated by $\mathrm{AMH}$ in L $\beta \mathrm{T} 2$ cells overexpressing Kiss-1R. However, these results should be interpreted with caution. Although L $\beta$ T2 cells express Kiss-1R, endogenous Kiss-1R does not respond to exogenous kisspeptin, suggesting that Kiss1R in L $\beta$ T2 cells was non-functional. The reason for the lack of function of endogenous Kiss-1R in L $\beta$ T2 cells is unknown; however, it is plausible that the original phenotype, as a gonadotroph cell line, is altered during cell preparation or repeated passage, and endogenous Kiss-1R levels might be insufficient to respond to kisspeptin. Therefore, in this study, we used L $\beta$ T2 cells overexpressing human Kiss-1R to examine the effect of AMH on Kiss1R function. Kiss-1R overexpression successfully activated intracellular signaling pathways, as determined by SRE promoter activity, and increased all three gonadotropin subunit genes, as determined by kisspeptin stimulation in Kiss-1Roverexpressing L $\beta$ T2 cells. However, the effects of kisspeptin on these genes were abolished by AMH. These observations indicate that in addition to the negative effect on endogenous Kiss-1R expression, AMH interferes with the function of Kiss-1R to induce gonadotropin subunit expression by kisspeptin stimulation. Because AMH also decreased levels of Kiss-1 in L $\beta$ T2 cells, it might disrupt the autocrine-paracrine regulatory effects of kisspeptin on gonadotropin subunit expression.

The stimulation of gonadotropin subunits by $\mathrm{GnRH}$ was not affected by AMH in these cells. GnRH increased gonadotropin subunit expression via endogenous GnRH receptor in L $\beta$ T2 cells, irrespective of AMH. Therefore, 
the suppressive effect of AMH on gonadotropin subunit gene expression might be related to kisspeptin and Kiss$\mathrm{R}$. The mechanism by which AMH hampers the effect of kisspeptin on gonadotropin subunit gene expression is unclear. AMH recruits Smad proteins by specific binding to AMHR2, and Smad proteins are translocated to the nucleus to regulate target gene expression [34]. The AMH-induced disruption of gonadotropin subunit gene expression might occur at the transcriptional level and is not ERK-dependent but mediates other kisspeptin-related pathways.

In this study, we used L $\beta$ T2 cells to study the physiology of normal gonadotrophs, the only established model of pituitary gonadotrophs able to produce all gonadotropin subunits, $\alpha, \operatorname{LH} \beta$, and FSH $\beta$. Therefore, we predicted that in normal gonadotrophs with functional endogenous Kiss-1R, AMH might weaken the effects of Kiss-1R on gonadotropin gene expression by reducing its expression and weakening its receptor functions, which are also associated with gonadotropin gene expression. AMH by itself could increase FSH $\beta$-subunit gene expression, even though it repressed the kisspeptin-induced increases in FSH $\beta, \alpha$, and FSH $\beta$. The importance of $\mathrm{AMH}$ for gonadotroph physiology is still largely unclear; however, our results suggest that $\mathrm{AMH}$ has protective effects on FSH synthesis in gonadotrophs.

Although the direct effect of AMH on pituitary gonadotrophs has been reported previously [17-19, 33], AMH also acts upstream of gonadotrophs. AMHR2 is expressed in GnRH neurons in mice and humans and is involved in GnRH-dependent increases in LH pulsatility and secretion [16]. A recent study has shown that GnRH suppresses the serum level of AMH [35]. In gonadotrophs, AMH could increase FSH $\beta$ expression; however, previous work has shown that FSH can suppress AMH at certain stages of the menstrual cycle in females [36]. Furthermore, it still unclear whether gonad-derived or locally produced AMH affects gonadotrophs or whether AMH has sex-specific functions. Further investigations are needed to elucidate the detailed regulatory effects of $\mathrm{AMH}$ on the HPG axis.

In this study, using pituitary gonadotroph L $\beta$ T2 cells, we showed that AMH specifically increases FSH $\beta$ subunit expression and reduces the levels of both the Kiss-1 and Kiss-1R genes. AMH inhibited the effect of kisspeptin on gonadotropin gene expression in Kiss1Roverespressing L $\beta$ T2 cells. AMH might interact with the Kiss-1/Kiss-1R system in target cells.

\section{Acknowledgements}

This work was supported in part by a Grant-in-Aid for Scientific Research from the Ministry of Education, Culture, Sports, Science and Technology of Japan (to H.K. and A.O.).

\section{Disclosure Statement}

The authors have no conflicts of interest to disclose.

\section{References}

1. Pinilla L, Aguilar E, Dieguez C, Millar RP, Tena-Sempere M (2012) Kisspeptins and reproduction: physiological roles and regulatory mechanisms. Physiol Rev 92: 12351316.

2. Crowley WF Jr, Filicori M, Spratt DI, Santoro NF (1985) The physiology of gonadotropin-releasing hormone (GnRH) secretion in men and women. Recent Prog Horm Res 41: 473-531.

3. Gharib SD, Wierman ME, Shupnik MA, Chin WW (1990) Molecular biology of the pituitary gonadotropins. Endocr Rev 11: 177-199.

4. Smith JT, Cunningham MJ, Rissman EF, Clifton DK, Steiner RA (2005) Regulation of Kiss1 gene expression in the brain of the female mouse. Endocrinology 146: 36863692.

5. Smith JT, Popa SM, Clifton DK, Hoffman GE, Steiner RA (2006) Kiss1 neurons in the forebrain as central processors for generating the preovulatory luteinizing hormone surge. J Neurosci 26: 6687-6694.

6. Clarkson J, d'Anglemont de Tassigny X, Colledge WH,
Caraty A, Herbison AE (2009) Distribution of kisspeptin neurones in the adult female mouse brain. $J$ Neuroendocrinol 21: 673-682.

7. Kadokawa H, Suzuki S, Hashizume T (2008) Kisspeptin-10 stimulates the secretion of growth hormone and prolactin directly from cultured bovine anterior pituitary cells. Anim Reprod Sci 105: 404-408.

8. Gutierrez-Pascual E, Martinez-Fuentes AJ, Pinilla L, Tena-Sempere M, Malagon MM, et al. (2007) Direct pituitary effects of kisspeptin: activation of gonadotrophs and somatotrophs and stimulation of luteinising hormone and growth hormone secretion. J Neuroendocrinol 19: 521-530.

9. Hara T, Kanasaki H, Tumurbaatar T, Oride A, Okada H, et al. (2019) Role of kisspeptin and Kiss1R in the regulation of prolactin gene expression in rat somatolactotroph GH3 cells. Endocrine 63: 101-111.

10. Josso N, Picard JY, Rey R, di Clemente N (2006) Testicular anti-Mullerian hormone: history, genetics, regulation and clinical applications. Pediatr Endocrinol Rev 3: 347- 
358.

11. Grinspon RP, Bedecarras P, Ballerini MG, Iniguez G, Rocha A, et al. (2011) Early onset of primary hypogonadism revealed by serum anti-Mullerian hormone determination during infancy and childhood in trisomy 21 . Int $J$ Androl 34: e487-e498.

12. Durlinger AL, Kramer P, Karels B, de Jong FH, Uilenbroek JT, et al. (1999) Control of primordial follicle recruitment by anti-Mullerian hormone in the mouse ovary. Endocrinology 140: 5789-5796.

13. Edelsztein NY, Grinspon RP, Schteingart HF, Rey RA (2016) Anti-Mullerian hormone as a marker of steroid and gonadotropin action in the testis of children and adolescents with disorders of the gonadal axis. Int $J$ Pediatr Endocrinol 2016: 20.

14. Broekmans FJ, Visser JA, Laven JS, Broer SL, Themmen AP, et al. (2008) Anti-Mullerian hormone and ovarian dysfunction. Trends Endocrinol Metab 19: 340-347.

15. Pigny P, Merlen E, Robert Y, Cortet-Rudelli C, Decanter C, et al. (2003) Elevated serum level of anti-mullerian hormone in patients with polycystic ovary syndrome: relationship to the ovarian follicle excess and to the follicular arrest. J Clin Endocrinol Metab 88: 5957-5962.

16. Cimino I, Casoni F, Liu X, Messina A, Parkash J, et al. (2016) Novel role for anti-Mullerian hormone in the regulation of GnRH neuron excitability and hormone secretion. Nat Commun 7: 10055.

17. Bedecarrats GY, O'Neill FH, Norwitz ER, Kaiser UB, Teixeira J (2003) Regulation of gonadotropin gene expression by Mullerian inhibiting substance. Proc Natl Acad Sci US A 100: 9348-9353.

18. Kereilwe O, Pandey K, Borromeo V, Kadokawa H (2018) Anti-Mullerian hormone receptor type 2 is expressed in gonadotrophs of postpubertal heifers to control gonadotrophin secretion. Reprod Fertil Dev 30: 1192-1203.

19. Kereilwe O, Kadokawa H (2019) Bovine gonadotrophs express anti-Mullerian hormone (AMH): comparison of AMH mRNA and protein expression levels between old Holsteins and young and old Japanese Black females. Reprod Fertil Dev 31: 810-819.

20. Richard N, Galmiche G, Corvaisier S, Caraty A, Kottler ML (2008) KiSS-1 and GPR54 genes are co-expressed in rat gonadotrophs and differentially regulated in vivo by oestradiol and gonadotrophin-releasing hormone. J Neuroendocrinol 20: 381-393.

21. Ezzat AA, Saito H, Sawada T, Yaegashi T, Goto Y, et al. (2010) The role of sexual steroid hormones in the direct stimulation by Kisspeptin-10 of the secretion of luteinizing hormone, follicle-stimulating hormone and prolactin from bovine anterior pituitary cells. Anim Reprod Sci 121: 267-272.

22. Srisuwatanasagul K, Srisuwatanasagul S, Roongsitthichai A (2021) Expressions of cytochrome P450 aromatase and anti-Mullerian hormone in testes of fattening pigs by the timing of the first vaccination for immunocastration. Reprod Domest Anim 56: 400-407.

23. Herber CB, Krause WC, Wang L, Bayrer JR, Li A, et al.
(2019) Estrogen signaling in arcuate Kiss1 neurons suppresses a sex-dependent female circuit promoting dense strong bones. Nat Commun 10: 163.

24. Dragan M, Nguyen MU, Guzman S, Goertzen C, Brackstone M, et al. (2020) G protein-coupled kisspeptin receptor induces metabolic reprograming and tumorigenesis in estrogen receptor-negative breast cancer. Cell Death Dis 11: 106.

25. Son YL, Ubuka T, Millar RP, Kanasaki H, Tsutsui K (2012) Gonadotropin-inhibitory hormone inhibits GnRHinduced gonadotropin subunit gene transcriptions by inhibiting AC/cAMP/PKA-dependent ERK pathway in LbetaT2 cells. Endocrinology 153: 2332-2343.

26. Yamada Y, Yamamoto H, Yonehara T, Kanasaki H, Nakanishi H, et al. (2004) Differential activation of the luteinizing hormone beta-subunit promoter by activin and gonadotropin-releasing hormone: a role for the mitogenactivated protein kinase signaling pathway in LbetaT2 gonadotrophs. Biol Reprod 70: 236-243.

27. Mijiddorj T, Kanasaki H, Oride A, Hara T, Sukhbaatar U, et al. (2017) Interaction between kisspeptin and adenylate cyclase-activating polypeptide 1 on the expression of pituitary gonadotropin subunits: a study using mouse pituitary lbetaT2 cells. Biol Reprod 96: 1043-1051.

28. Wong ML, Medrano JF (2005) Real-time PCR for mRNA quantitation. Biotechniques 39: 75-85.

29. Bustin SA, Benes V, Nolan T, Pfaffl MW (2005) Quantitative real-time RT-PCR--a perspective. J Mol Endocrinol 34: 597-601.

30. Seminara SB, Messager S, Chatzidaki EE, Thresher RR, Acierno JS Jr, et al. (2003) The GPR54 gene as a regulator of puberty. N Engl J Med 349: 1614-1627.

31. Mijiddorj T, Kanasaki H, Sukhbaatar U, Oride A, Hara T, et al. (2017) Mutual regulation by GnRH and kisspeptin of their receptor expression and its impact on the gene expression of gonadotropin subunits. Gen Comp Endocrinol 246: 382-389.

32. Wang PY, Koishi K, McGeachie AB, Kimber $M$, Maclaughlin DT, et al. (2005) Mullerian inhibiting substance acts as a motor neuron survival factor in vitro. Proc Natl Acad Sci U S A 102: 16421-16425.

33. Garrel G, Racine C, L'Hote D, Denoyelle C, Guigon CJ, et al. (2016) Anti-Mullerian hormone: a new actor of sexual dimorphism in pituitary gonadotrope activity before puberty. Sci Rep 6: 23790.

34. Josso N, Clemente N (2003) Transduction pathway of anti-Mullerian hormone, a sex-specific member of the TGF-beta family. Trends Endocrinol Metab 14: 91-97.

35. van Helden J, Evliyaoglu O, Weiskirchen R (2019) Has $\mathrm{GnRH}$ a direct role in AMH regulation? Clin Endocrinol (Oxf) 90: 827-833.

36. Dewailly D, Robin G, Peigne M, Decanter C, Pigny P, et al. (2016) Interactions between androgens, FSH, antiMullerian hormone and estradiol during folliculogenesis in the human normal and polycystic ovary. Hum Reprod Update 22: 709-724. 